\title{
PREDIKSI PASOKAN BAWANG MERAH MENDUKUNG DESAIN PENGEMBANGAN AGROINDUSTRI DI PROVINSI ACEH
}

\section{SHALLOT SUPPLY PREDICTION SUPPORTING AGROINDUSTRY DEVELOPMENT DESIGNS IN ACEH PROVINCE}

\author{
Rizki Ardiansyah" ${ }^{1}$, Rachman Jaya ${ }^{1)}$, Yusriana ${ }^{2)}$, Cut Hilda Rahmi ${ }^{1)}$ \\ ${ }^{1)}$ Balai Pengkajian Teknologi Pertanian Aceh \\ J1. Panglima Nyak Makam No. 27 Lampineung, Banda Aceh, Indonesia 23125, Indonesia \\ *Email: ardiansyah.rizki@gmail.com \\ 2) Jurusan Teknologi Hasil Pertanian, Fakultas Pertanian Universitas Syiah Kuala, Darussalam, Banda Aceh 23111, Indonesia
}

Makalah: Diterima 16 Desember 2020; Diperbaiki 23 Maret 2021; Disetujui 06 April 2021

\begin{abstract}
One of the important of agricultural commodities to be developed is shallot. It has significantly contributed on national and regional inflation. Although, Aceh Povince is not a national production centre of shallot, it has some shallot production centres, namely at Pidie, Aceh Tengah, and Aceh Besar districts. The main characteristics of shallot are seasonal and perishable, thus they should be effectively handled. The objectives of this research were to obtain production shallot pattern and to design an agroindustrial model which suitable with shallot production characteristics. Method used was Auto Regresive Moving Average (ARIMA), the data used were time-series (monthly) for 6 month, whereas option design model and product used Analitical Hierarcy Process (AHP). The result of study shows that a model of $A R I M A(p, d, q)$ was $(0,0,1)$ with mean square of 20,682,669. Meanwhile, the prediction of production $t_{+1}=6.662$ kuintal. The options of model designs were micro scale agroindustry with a weight (0.59) and small scale agroindustry (0.25), whereas the main products were pasta (0.41), shallot (0.26), and cutted shallot (0.19).
\end{abstract}

Key words: agroindustrial, ARIMA, AHP, shallot

\section{ABSTRAK}

Bawang merah merupakan salah satu komoditas hortikultura penting dan mendapatkan perhatian pemerintah karena komoditas ini memiliki kontribusi terhadap inflasi, baik lokal maupun nasional. Walaupun bukan merupakan sentra produksi nasional, Provinsi Aceh memilki sentra produksi bawang merah, yaitu di Kabupaten Pidie, Aceh Tengah, dan Aceh Besar. Karakteristik menonjol produk pertanian antara lain adalah musiman dan mudah mengalami kerusakan sehingga diperlukan penggelolaan yang efektif. Tujuan kajian ini adalah untuk mengetahui pola produksi bawang merah dan merancang desain agroindustri yang sesuai dengan karakteristik produksi. Metode yang digunakan adalah Auto Regresive Moving Average (ARIMA), data yang digunakan adalah time-series (bulanan) selama 6 tahun terakhir, sedangkan desain opsi bentuk dan produk agroindustri menggunakan Analitical Hierarcy Process (AHP). Hasil penelitian menunjukkan model ARIMA (p,d,q) yang sesuai adalah $(0,0,1)$, dengan Mean-Square 20,682,669. Prediksi produksi $\mathrm{t}_{+1}=6.662 \mathrm{kuintal}$, sedangkan opsi desain skala agroindustri adalah mikro dengan bobot $(0,59)$ dan kecil $(0,25)$ dengan prioritas produk utama adalah pasta $(0,41)$, bawang utuh $(0,26)$, dan bawang iris $(0,19)$.

Kata kunci: agroindustri, ARIMA, AHP bawang merah

\section{PENDAHULUAN}

Bawang merah (Allium cepa L.) merupakan salah satu komoditas penting di Indonesia. Kementerian Pertanian Republik Indonesia telah menetapkan 7 komoditas utama sektor pertanian, dan salah satunya adalah bawang merah. Dari sisi ekonomi, Bank Indonesia (2020), menyatakan bahwa bawang merah adalah salah satu komoditas yang berkontribusi dalam inflasi dengan nilai 5,04 persen. Khusus untuk Provinsi Aceh, fakta Mei-Juni 2020 harga komoditas ini di pasar-pasar tradisional ratarata berkisar Rp.45.000-65.000/kg. Pada sisi yang lain saat panen raya, harga bawang merah berkisar Rp.20.000-30.000/kg (Syafa'at et al., 2006;
Kemendag, 2016; BPS, 2019). Hal ini menunjukkan bahwa fluktuasi harga komoditas bawang merah sangat tinggi, untuk itu diperlukan cara mengatasi hal tersebut, yaitu dengan memperpanjang umur simpan (self-life), mengolahnya menjadi produk siap untuk digunakan (ready to use) sebagai bumbu, atau dengan produk olahan lainnya, seperti bawang goreng. Dalam rangka optimalisasi sumberdaya pertanian dan meningkatkan nilai tambah bawang merah maka perlu didorong hilirisasi produk pertanian melalui pengembangan agroindustri.

Agroindustri adalah industri yang mengolah hasil pertanian (Austin, 1992; Brown, 1994), dalam bentuk bahan setengah jadi atau bahan jadi. Agroindustri menjadi pendekatan yang sangat 
penting, dalam pembangunan pertanian secara keseluruhan. Titik tolak pembangunan agroindustri adalah peningkatan nilai tambah (value-added), sehingga manfaat yang didapatkan oleh pelaku jauh lebih besar dibandingkan dengan produk primer. Desain agroindustri berbasis komoditas bawang merah telah dilakukan oleh Herman (2007) di wilayah sentra produksi bawang merah nasional, agroindustri bawang merah berbasis klaster (Sofiyessi et al., 2020), sedangkan daya saing komoditas ini dikaji oleh Aldila et al. (2017).

Dilihat dari segi geografis, Provinsi Aceh tidak termasuk sentra produksi bawang merah nasional, akan tetapi komoditas ini penting dalam pembangunan sektor pertanian secara regional. Permintaan bawang merah Aceh diperkirakan mencapai 33.000 ton/tahun, dengan harga rata-rata Rp. 35.000/kg, maka dibutuhkan dana sampai Rp 1.1 Trilyun untuk memenuhi kebutuhan Provinsi Aceh. Dari sisi pasokan, tidak lebih dari 20\% kebutuhan tersebut dapat dipenuhi secara lokal dengan luas panen 1.133 ha (Gambar 1), tetapi proporsi 20\% tersebut menyebabkan harga turun secara drastis, sehingga diperlukan langkah teknis untuk mengatasi hal tersebut. Sentra produksi komoditas ini terdapat di Kabupaten Pidie, Aceh Besar dan Aceh Tengah. Berdasarkan penggunaanya, umumnya bawang merah sepenuhnya digunakan untuk bumbu, dalam pengertian bahwa penggunaan bawang merah dalam keadaan segar.

Alternatif yang dapat dilakukan oleh pelaku bisnis/agroindustri adalah mengolah bawang merah pada saat musim panen/harga turun. Beberapa kajian olahan komoditas bawang merah telah dilakukan oleh Anggarini et al. (2014) pada produk puree, Permatasari et al. (2017) untuk produk pasta atau dalam produk utuh bawang merah (umbi) dalam brine (larutan garam) (Risfaheri et al., 2018). Secara umum opsi olahan ini menggambarkan bahwa fungsi bawang merah sebagai bumbu dan obat tradisional tetap terjaga. Olahan lain yang juga memiliki prospek untuk dikembangkan adalah bawang goreng (Khamidah dan Murni, 2017; Tulipa et al., 2020) dan acar (Minh, 2019).

Pada bagian awal telah diuraikan bahwa harga dapat berfluktuasi secara signifikan pada satuan waktu tertentu. Untuk mengatasi hal tersebut, salah satu cara yang dapat dilakukan adalah mengembangkan agroindustri berbasis komoditas bawang merah. Hal mendasar yang harus dilakukan adalah dengan mengetahui dan memastikan bahwa kategori agroindustri seperti apa yang cocok untuk dikembangkan serta produk olahan apa yang sesuai dengan keinginan mayoritas masyarakat Provinsi Aceh. Untuk menjawab permasalahan tersebut diperlukan kajian desain pembentukan agroindustri bawang merah di Provinsi Aceh. Kajian ini dibatasi pada desain dasar berbasis prediksi pasokan, opsi produk olahan dan kategori industri yang memiliki prospek baik untuk dikembangkan. Tujuan dari penelitian ini adalah memprediksi pasokan bawang merah sebagai bahan baku industri olahan bawang merah.

\section{METODE PENELITIAN}

\section{Kerangka Pemikiran}

Dasar pelaksanaan kajian adalah pentingnya pengembangan agroindustri bawang merah di Provinsi Aceh. Titik tolak kajian adalah tingginya fluktuasi harga bawang merah saat musim panen dan paceklik bersifat inelastisitas (Kustiari, 2017). Pada sisi yang lain, terdapat sentra produksi di Provinsi Aceh, yaitu Kabupaten Pidie, Aceh Tengah dan Aceh Besar. Hal penting lainnya adalah fungsi bawang merah sebagai bumbu yang tidak tergantikan, dengan pengertian bahwa kondisi bawang merah saat digunakan dalam keadaan basah.

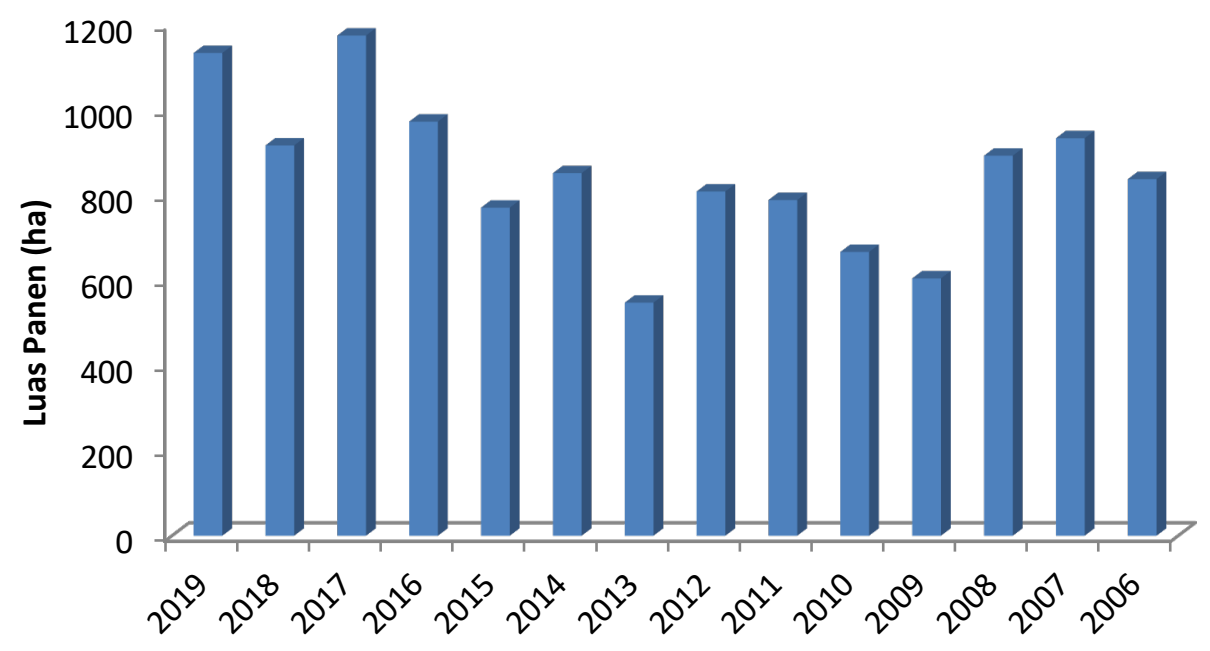

Gambar 1. Luas panen bawang merah Provinsi Aceh ([Distanbun] Provinsi Aceh, 2020) 
Hasil kajian menunjukkan terdapat beberapa alternatif olahan yang cukup potensial seperti puree, pasta dan bawang merah dalam bentuk utuh (Anggarini et al., 2014; Permatasari et al., 2017). Beberapa hasil kajian menunjukkan bahwa terdapat beberapa opsi olahan yang masih mendeskripsikan fungsi bawang merah sebagai bumbu belum berubah. Beberapa opsi tersebut antara lain: puree, pasta dan bawang merah dalam bentuk utuh.

Dalam kajian ini prediksi pasokan (lokal) merupakan produksi bawang merah Provinsi Aceh, sedangkan opsi olahan mengacu pada usaha memperpanjang umur simpan tanpa merubah sifat fungsional dari bawang merah, sedangkan kategori industri merujuk pada kriteria industri yang sesuai Peraturan Menteri Perindustrian Nomor: 20/2016 tentang industri rumah tangga, industri kecil, industri menengah (Kemenperin, 2016). Tujuan (goal) yang ingin dicapai adalah fluktasi harga dapat diturunkan melalui aplikasi beberapa olahan, adanya peningkatan nilai tambah, dan sebagai solusi atas ketersediaan bawang merah sebagai bumbu dan obat tradisional dari waktu ke waktu.

\section{Tata Laksana Kajian}

Prediksi pasokan bawang merah menggunakan data runut waktu (time-series) 20142018 (BPS, 2019). Metode prediksi yang digunakan adalah autoregressive moving average (ARIMA) atau yang lebih dikenal dengan metode Box-Jenkins (Nochai, 2006). Kelebihan dari metode ini adalah kemampuan menduga pola dari data runut waktu, termasuk juga yang sering terjadi pada komoditas pertanian, yaitu adanya pola musiman (seasonal). Desain opsi produk dan kategori industri yang diaplikasikan diformulasi dengan teknik Analytical Hierarchy Process (AHP). Teknik ini cukup baik digunakan pada proses seleksi berdasarkan beberapa opsi dan kriteria (García et al., 2014).

Kajian dilaksanakan Bulan Mei-Juli 2020. Proses prediksi pasokan bawang merah dilakukan dengan alat bantu aplikasi Minitab versi 16 for window, sedangkan seleksi jenis produk dan kategori industri diformulasi berdasarkan pendapat pakar. Jumlah pakar yang terlibat 3 orang dengan profesi sebagai peneliti, akademisi dan praktisi.

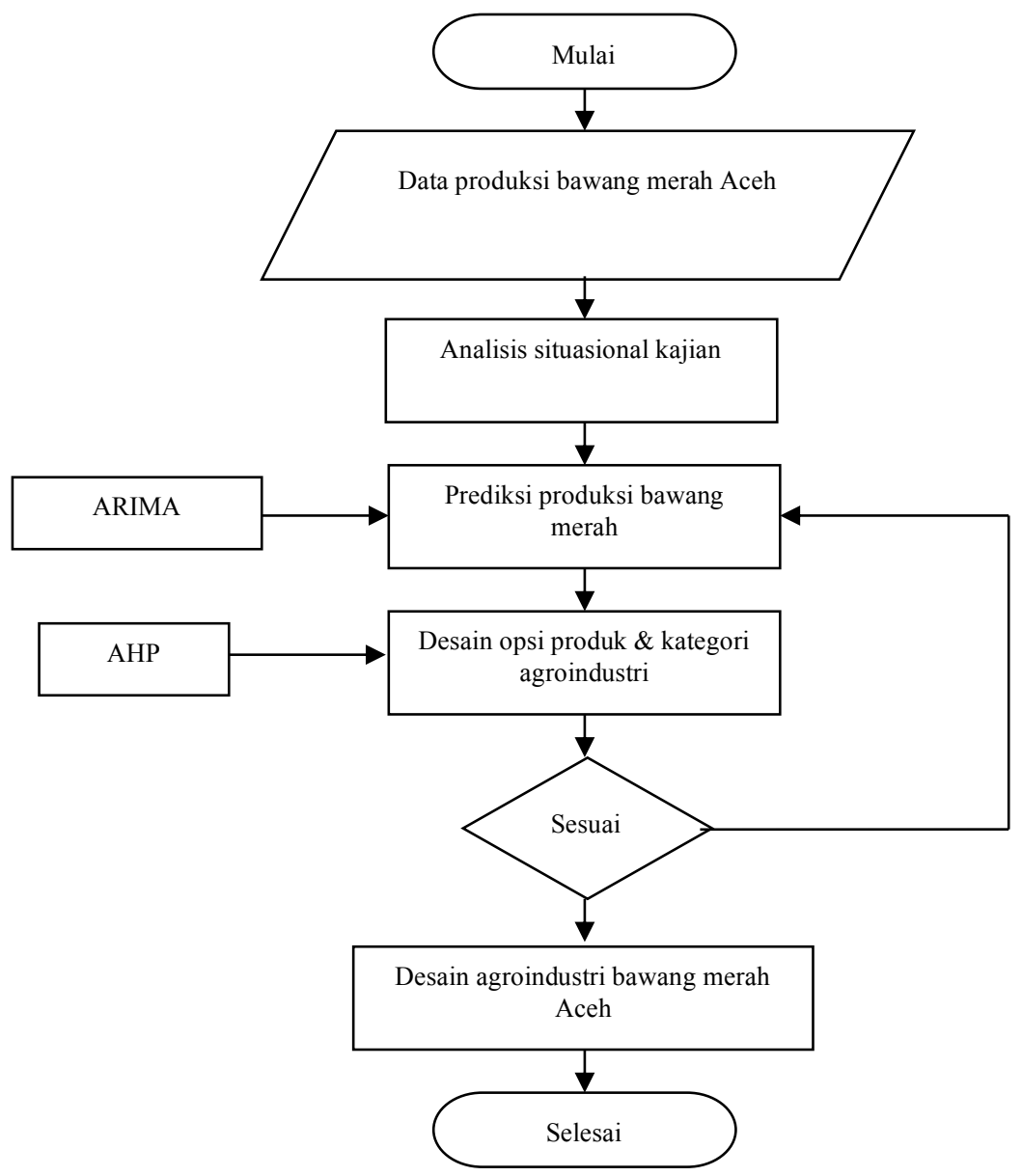

Gambar 2. Tata laksana kajian 


\section{Pemodelan ARIMA}

Kualifikasi peneliti dan akademisi bergelar Doktor pada bidang agroindustri, sedangkan praktisi minimal bergelar sarjana dan telah menekuni bidang pengembangan agroindustri minimal 10 tahun. Secara umum, Model ARIMA dikelompokkan dalam 3 unsur, yaitu: Model autoregresif (AR), moving average (MA), dan Integrasi (I). Ketiga unsur ini dapat dimodifikasi sehingga membentuk model baru misalnya model autoregresif dan moving average (ARMA). Namun, apabila dibuat dalam bentuk umumnya menjadi ARIMA (p,d,q), maka p menyatakan ordo AR, d menyatakan ordo integrasi dan q menyatakan ordo Moving average. Jika modelnya menjadi AR, maka model umumnya menjadi ARIMA $(1,0,0)$, untuk lebih jelasnya berikut uraian untuk masing-masing unsur.

\section{Autoregresif}

Bentuk umum dari model autoregresif dengan ordo $\mathrm{p}(\mathrm{AR}(\mathrm{p}))$ atau model $\operatorname{ARIMA}(\mathrm{P}, 0,0)$ dinyatakan sebagai berikut:

$$
\begin{aligned}
& X t=\mu^{\prime}+\emptyset 1 X t-1+\emptyset 2 X t-2+\cdots+\emptyset p X t- \\
& p+e t
\end{aligned}
$$

\section{Keterangan:}

$\mu^{\prime}=$ suatu konstanta $\emptyset p=$ parameter autoregresif ke-p et $=$ nilai kesalahan pada saat $t$, pengertian dari autoregresif yaitu nilai $\mathrm{X}$ dipengaruhi oleh nilai $\mathrm{x}$ periode sebelumnya hingga periode ke-p, sehingga yang berpengaruh disini adalah variabel itu sendiri.

\section{Moving average}

Bentuk umum dari model moving average dengan ordo q $(\mathrm{MA}(\mathrm{q}))$ atau model $\operatorname{ARIMA}(0,0, \mathrm{q})$ dinyatakan sebagai berikut:

$X t=\mu^{\prime}+e t-\theta 1$ et $-1-\theta 2$ et $-2-\cdots-\theta t-k$

Keterangan:

$\mu^{\prime}=$ suatu konstan $\theta 1$ sampai $\theta q$ adalah parameter-parameter moving average et $-k=$ nilai kesalahan pada saat $-\mathrm{k}$. Pengertian dari moving average yaitu nilai variabel $\mathrm{x}$ dipengaruhi oleh error dari varibel $\mathrm{x}$ tersebut.

\section{Integrasi}

Bentuk umum dari model integrasi dengan ordo d (I(d)) atau model ARIMA $(0, d, 0)$. Pengertian integrasi menyatakan difference dari data. Dalam membuat model ARIMA syarat yang harus dipenuhi adalah stasioneritas data. Jika data stasioner pada level maka ordonya sama dengan 0 , namun apabila stasioner pada different pertama maka ordonya 1, demikian seterusnya. Model ARIMA dibagi dalam 2 bentuk, yaitu model ARIMA tanpa musiman dan model ARIMA musiman. Model ARIMA tanpa musiman merupakan model ARIMA yang tidak dipengaruhi oleh faktor waktu musim. Bentuk umum dapat dinyatakan dalam persamaan berikut:

$1-B 1-\emptyset 1 B X t=\mu^{\prime}+1-\theta 1 B e$

ARIMA musiman merupakan model ARIMA yang dipengaruhi oleh faktor waktu musim. Model ini biasa disebut Season ARIMA (SARIMA). Bentuk umum dinyatakan sebagai berikut:

$1-B 1-B^{\mathrm{i}} 2 X t=1-\theta t B 1-\theta 1 B^{\mathrm{i}} 2$ et

\section{Analytical Hierarchy Process (AHP)}

AHP adalah suatu teknik pendukung keputusan yang dikembangkan oleh Thomas L. Saaty. Model berbasis pendekatan multi kriteria dalam bentuk struktur hirarki. Menurut (Saaty, 2008), hirarki didefinisikan sebagai suatu representasi dari sebuah permasalahan yang kompleks dalam suatu struktur multi-level, dimana level pertama adalah sebagai dasar level pada olahan produk bawang merah. Dalam kajian ini penentuan alternatif produk olahan dan kategori industri hanya berbasis pada kriteria.

Secara teknis operasional, AHP adalah penyusunan struktur hirarki yang terdiri dari tujuan (goal), kriteria dan alternatif (opsi). Pada masingmasing kriteria dan opsi alternatif dilakukan perbandingan berpasangan (pairwaise comparison) melalui alat bantu kuesioner, yang kemudian diisi oleh pakar yang terlibat. Skala pengukuran (Tabel 1) berupa tingkat kepentingan (1-9). Pengolahan data dengan bantuan perangkat lunak excel-solver for window 2010. Demikian juga pengukuran konsistensi rasio dari pendapat pakar, jika terjadi ketidakkonsistenan pendapat, maka akan dilakukan penyesuaian/perbaikan pendapat terhadap pakar.

Tabel 1. Skala Penilaian

\begin{tabular}{cl}
\hline $\begin{array}{c}\text { Skala } \\
\text { Penilaian }\end{array}$ & \multicolumn{1}{c}{ Definisi } \\
\hline 1 & $\begin{array}{l}\text { Kedua kriteria sama penting } \\
\text { Kriteria satu sedikit lebih penting } \\
\text { dari pada yang lainnya } \\
\text { Kriteria satu sangat penting } \\
\text { dibandingkan yang lainnya }\end{array}$ \\
5 & $\begin{array}{l}\text { Kriteria satu jelas lebih penting } \\
\text { dari kriteria yang lainnya }\end{array}$ \\
9 & $\begin{array}{l}\text { Kriteria satu mutlak lebih penting } \\
\text { dari kriteria yang lainnya } \\
\text { Nilai di antara keduanya jika } \\
\text { terjadi keraguan }\end{array}$ \\
\hline
\end{tabular}

\section{HASIL DAN PEMBAHASAN}

\section{Prediksi pasokan bawang merah}

Pokok bahasan pasokan digunakan untuk memprediksi jumlah pasokan lokal berdasarkan 
jumlah dan waktu yang dapat digunakan oleh agroindustri. Diketahuinya jumlah pasokan, agroindustri dapat menyusun skenario pasokan, jika terjadi kekurangan pasokan. Secara umum, pada pasokan/produksi bawang merah Provinsi Aceh terjadi fluktuasi (Gambar 3a). Hal ini disebabkan oleh musim panen yang berbeda antara wilayah sentra produksi, yaitu Kabupaten Pidie, Aceh Tengah dan Aceh Besar. Fluktuasi pasokan juga disebabkan oleh terhentinya proses budidaya bawang karena pada periode musim tanam (Oktober-Maret) lahan digunakan untuk menanam padi, hal ini terjadi di Kabupaten Pidie. Fluktuasi produksi ini yang menyebabkan juga terjadinya fluktuasi harga.

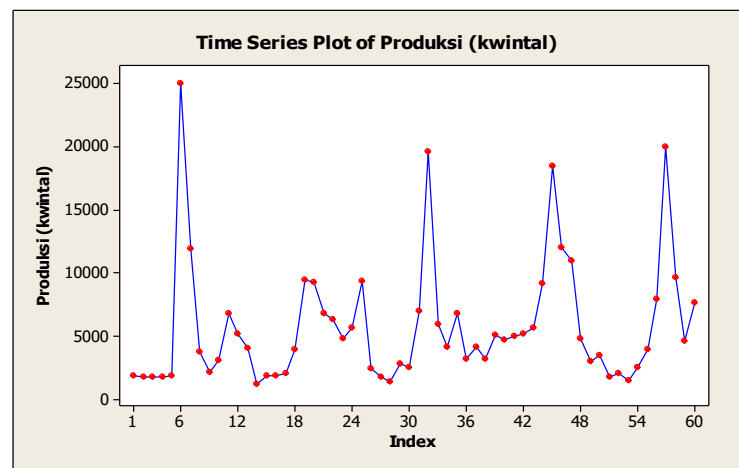

Gambar 3a. Pasokan lokal bawang merah Provinsi Aceh (2014-2018)

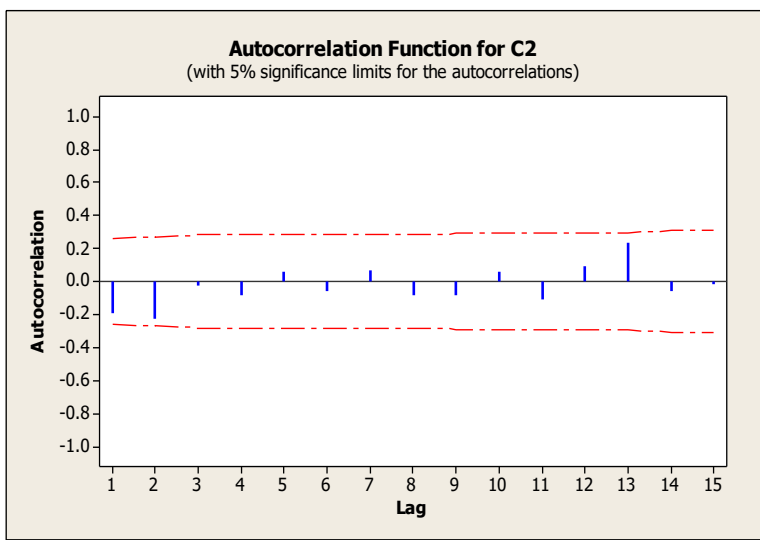

Gambar 3b. ACF pasokan bawang merah Provinsi Aceh

Gambar 3a, b, c, menunjukkan bahwa data pasokan stasioner terhadap nilai tengah (mean value), sehingga tidak perlu dilakukan pembedaan (differencing). Dalam hal ini model ARIMA yang dipilih adalah $(0,0,1)$, dengan parameter dapat dilihat pada Tabel 2. Berdasarkan Tabel 2, terlihat bahwa model ARIMA yang dapat digunakan adalah $(0,0,1) / \mathrm{MA} 1$, dengan nilai $p 0,000$ (sangat signifikan pada $\alpha 5 \%$ ) dan MS 20,682,669 serta dengan nilai forecast pada lag 61 sebesar 6,662 kuintal/bulan. Estimasi produksi tertinggi 15,557 kuintal dan terendah 2,253 kuintal. Data ini akan digunakan sebagai salah satu input untuk membuat desain agroindustri bawang merah di Provinsi Aceh.

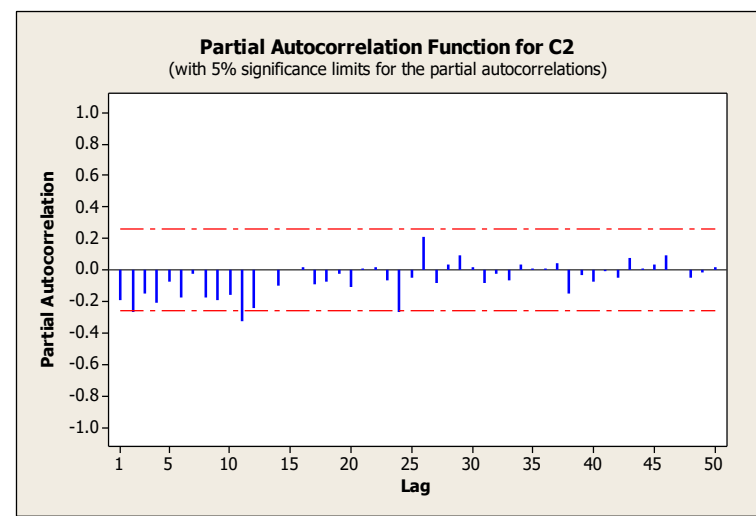

Gambar 3c. PACF pasokan bawang merah Provinsi Aceh

\section{Penentuan Alternatif Jenis Olahan}

Selain fokus pada sistem produksi (pasokan), desain pengembangan agroindustri bawang merah di Provinsi Aceh juga membahas aspek seleksi terhadap opsi jenis olahan yang dapat diimplementasikan oleh agroindustri. Dasar penentuan opsi adalah kriteria (Gambar 4) yang dikembangkan atas kesiapan dan kemudahan teknologi (inovasi) serta kesesuaian dengan pengguna, dalam hal ini mengacu pada aspek sosial-budaya (kewilayahan) (Anggarini et al., 2014; Permatasari et al., 2017).

\section{Penentuan Alternatif Skala Agroindustri}

Salah satu point penting dari kajian ini adalah skala agroindustri yang cocok untuk dikembangkan di Provinsi Aceh. Acuan penentuan berupa kriteria yaitu tenaga kerja, aset dan modal yang dimiliki (Herman, 2007). Alternatif skala agroindustri yang akan diimplementasi disusun berdasarkan klasifikasi industri kecil, yang pada dasarnya dapat dikelompokkan menjadi medium enterprise, small enterprise dan micro enterprise (Gambar 5).

Tabel 2. Tabel estimasi model ARIMA $(0,0,1)$

\begin{tabular}{ccccccc}
\hline Tipe & Coef. & SE Coef. & T & $\boldsymbol{p}$ & MS & Forecast \\
\hline MA1 & $-0,438$ & 0,118 & $-3,71$ & 0,000 & $20,682,669$ & $61: 6,662$ kuintal
\end{tabular}

Ket: MS (mean square), Forecast: 6,662 kuintal 


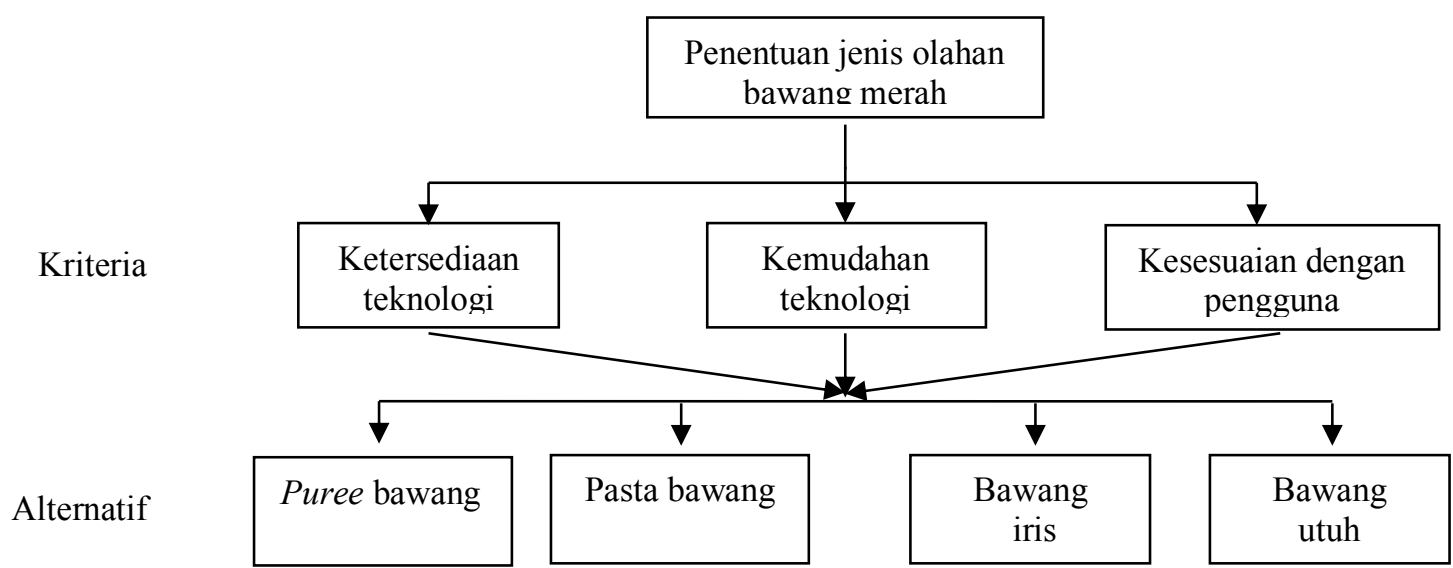

Ket: bawang utuh adalah bawang direndam dalam larutan garam

Gambar 4. Struktur hirarki penentuan alternatif jenis olahan

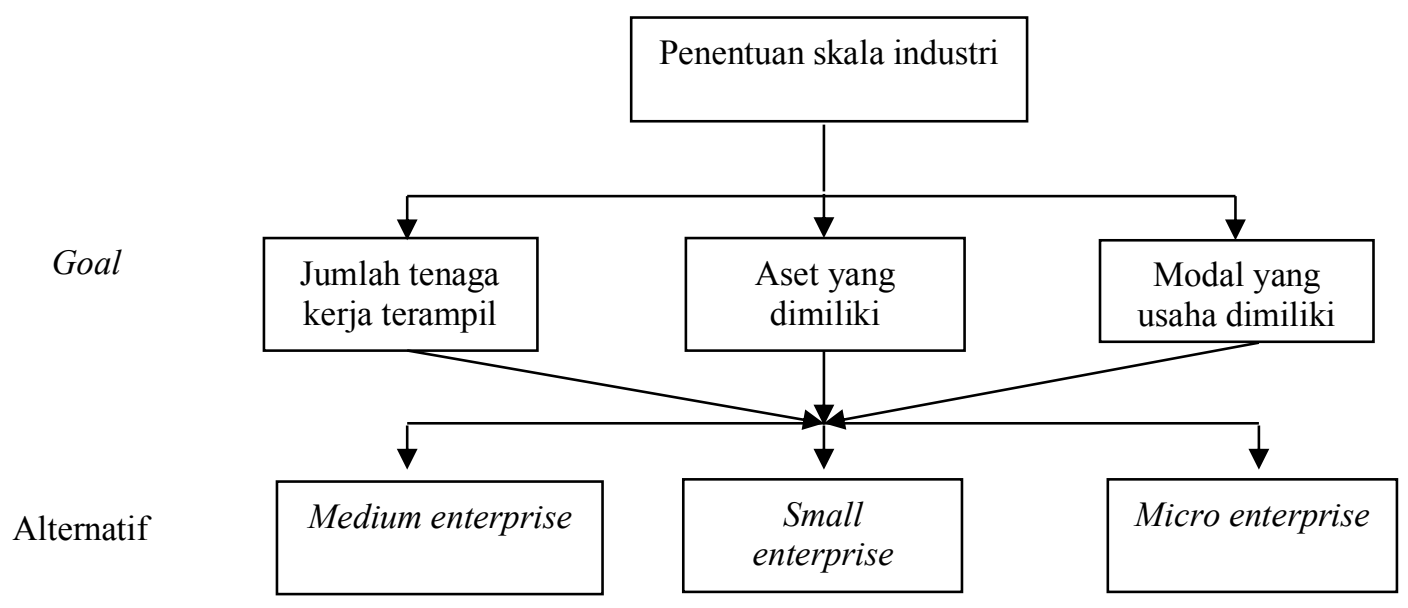

Gambar 5. Struktur hirarki penentuan alternatif skala agroindustri

Tabel 3. Matrik alternatif jenis olahan dan skala industri

\begin{tabular}{lccc|cccc}
\hline $\begin{array}{l}\text { Alternatif } \\
\text { jenis olahan }\end{array}$ & $\begin{array}{c}\text { Ketersediaan } \\
\text { teknologi }\end{array}$ & $\begin{array}{c}\text { Kemudahan } \\
\text { teknologi }\end{array}$ & $\begin{array}{c}\text { Kesesuaian } \\
\text { pengguna }\end{array}$ & Puree & Pasta & $\begin{array}{c}\text { Bawang } \\
\text { utuh }\end{array}$ & $\begin{array}{c}\text { Bawang } \\
\text { iris }\end{array}$ \\
\hline Bobot & 0,4 & 0,3 & 0,26 & 0,12 & 0,41 & 0,26 & 0,19 \\
\hline $\begin{array}{l}\text { Alternatif skala } \\
\text { agroindustri }\end{array}$ & $\begin{array}{c}\text { Jumlah tenaga } \\
\text { kerja terampil }\end{array}$ & $\begin{array}{c}\text { Aset yang } \\
\text { dimiliki }\end{array}$ & Modal & Menengah & Kecil & Mikro \\
\hline Bobot & 0,11 & 0,51 & 0,37 & 0,14 & 0,25 & 0,59 \\
\hline
\end{tabular}

Berdasarkan hasil analisis AHP, penentuan alternatif jenis olahan (Tabel 3) dengan nilai Consistency Ratio (CR) 0,41 (ambang batas 0,58) menunjukkan bahwa, dari aspek kriteria, secara umum bobot tertinggi terdapat pada ketersediaan teknologi $(0,40)$, kemudian kemudahan teknologi $(0,32)$. Hal ini menunjukan bahwa secara umum dalam perencanaan pembangunan agroindustri bawang merah di Provinsi Aceh aspek ketersediaan dan kemudahan teknologi sangat penting untuk menjadi perhatian bagi stakeholder yang terlibat. Dari sisi jenis olahan yang akan dikembangkan, produk pasta dengan bobot kepentingan $(0,41)$ merupakan prioritas utama, kemudian bawang utuh $(0,26)$.

Dari aspek alternatif skala industri yang dikembangkan berdasarkan kriteria, prioritas utama pembangunan agrindustri mencakup aset yang dimiliki dengan bobot $(0,51)$, selanjutnya aspek modal kerja $(0,37)$ dan prioritas terakhir adalah jumlah tenaga kerja $(0,11)$. Secara umum dalam penyusunan desain pembangunan agroindustri bawang merah di Provinsi Aceh, alternatif utama skala agroindustri adalah skala industri-mikro dengan bobot $(0,59)$, kemudian industri kecil $(0,25)$ dan menengah $(0,14)$. Alternatif skala agroindustri menjadi sangat penting seperti apa wujud agroindustri yang akan dikembangkan karena berhubungan dengan kriteria-kriteria utama pembangunan suatu agroindustri. Walaupun dalam jangka panjang dapat dilakukan penyesuaian-penyesuaian (skenario) oleh stakeholder terhadap skala agroindustri sesuai dengan dinamika situasi terkini. 


\section{KESIMPULAN}

Berdasarkan analisa yang telah dilakukan, disimpulkan bahwa model prediksi pasokan bawang merah memiliki pola stasioner dengan nilai Arima $(0,0,1)$ dengan prediksi lag 61 6,662 kuintal. Untuk itu prioritas jenis olahan bawang merah adalah produk pasta bawang merah dengan skala industri mikro di Provinsi Aceh.

\section{UCAPAN TERIMA KASIH}

Secara khusus tim kajian mengucapkan terima kasih kepada Safwan Fahmi dari Dinas Pertanian dan Perkebunan Provinsi Aceh yang telah mambantu dalam penyediaan dan sinkronisasi data produksi bawang merah Provinsi Aceh.

\section{DAFTAR PUSTAKA}

[BPS] Badan Pusat Statistik. 2019. Aceh Dalam Angka 2019. Banda Aceh.

[Kemendag] Kementerian Perindustrian. 2016. Profil Komoditas Barang Kebutuhan Pokok dan Barang Penting, Komoditas Bawang Merah. Jakarta.

[Kemenperin] Kementerian Perindustrian. 2016. Perubahan Ketiga Atas Peraturan Menteri Perindustrian Restrukturiasasi Mesin dan/atau Peralatan Industri Kecil dan Menengah. Jakarta.

[Distanbun] Dinas Pertanian dan Perkebunan Provinsi Aceh. 2020. Produksi dan Luas Panen Bawang Merah di Provinsi Aceh.

Aldila HF, Fariyanti A, dan Tinaprilla N. 2017. Daya saing bawang merah di wilayah sentra produksi di Indonesia. Jurnal Manajemen \& Agribisnis 14(1):43-53. doi: 10.17358/JMA.14.1.43.

Anggarini S, Pamungkas ETGD, dan Wignyanto. 2014. Pembuatan puree bawang merah dalam kajian kombinasi faktor konsentrasi sodium metabisulfit pada proses perendaman dan penambahan maltadekstrin. Jurnal Industria 3(3):138-144.

Austin JE. 1992. Agroindustrial Project Analysis : Critical Design Factors. Economic D. Maryland: Johns Hopkins University Press.

Brown J. 1994. Agroindustrial Investment and Operation. Washington DC: The World Bank.

García JL, Alvarado A, Blanco J, Jimenez E, Maldonado AA, Cortez G. 2014. Multi- attribute evaluation and selection of sites for agricultural product warehouses based on an Analytic Hierarchy Process. Computers and Electronics in Agriculture 100:60-69. doi: 10.1016/j.compag.2013.10.009.

Herman AS. 2007. Model agroindustri bawang merah brebes. Riset Industri 1(1):45-58.

Khamidah A dan Murni WS. 2017. Pembuatan bawang merah goreng untuk mengurangi kehilangan hasil di saat panen raya. in Seminar Nasional dan Gelar Produk. 1182-1192.

Kustiari R. 2017. Perilaku harga dan integrasi pasar bawang merah di Indonesia. Jurnal Agro Ekonomi. 35(2):77-87.

Marimin 2004. Teknik dan Aplikasi Pengambilan Keputusan Kriteria Majemuk. Jakarta: Penerbit Grasindo. doi: 10.13140/RG.2.1.3743.2800.

Minh NP. 2019. Technical Factors affecting to pickle shallot (allium ascalonicum) fermentation. Journal Pharm. Sci. \& Res 11(3):879-881.

Nochai R. 2006. ARIMA Model Forecasting Oil Palm Price. in Proceeding of the 2nd IMT-GT Regional Conference on Mathematics, Statistics and Application 1-8. Penang.

Permatasari NA, Yuliasih I, dan Suryani A. 2017. Proses pembuatan pasta bawang merah (Allium cepa var. aggregatum) dan penentuan umur simpannya dalam kemasan gelas. Jurnal Teknologi Industri Pertanian. 27(2):200-208. doi: 10.24961/j.tek.ind.pert.2017.27.2.200.

Risfaheri, Handayani AA, dan Setyadjit. 2018. Optimasi produksi bawang merah utuh (Allium ascalonicum L) in Brine. Jurnal Penelitian Pascapanen Pertanian. 15(1):2535.

Saaty TL. 2008. Decision making with the analytic hierarchy process. International Journal Services Sciences 1(1):83-98. doi: 10.1504/IJSSCI.2008.017590.

Syafa'at N, Hadi PU, Purwoto A, Sadra DK, Frans BD, Situmorang J. 2006. Proyeksi permintaan dan penawaran komoditas utama pertanian, 2005-2020. Pangan. 46(15):21-40.

Tulipa D, Rachmawati D, Ellitan L, Srianta I. 2020. Market research and cost analysis of production of fried shallot as local superior product in Semau Island, East Nusa Tenggara, Indonesia. Food Research. 4(2):343-348. 